\title{
PLEONASTIC USE OF VERBS OF SPEAKING IN GREEK: AN INTERPRETATION IN TERMS OF NATURALNESS THEORY
}

This paper investigates a special use of the verbs of speaking in Greek, in which a personal verbal form of a verb of speaking is accompanied by a participle of another verb of speaking. The latter is used pleonastically because the clause would be grammatical if the participle were omitted; cf. Chr. J. Mal. 15, 13, 31: ${ }^{\circ} \mathrm{O} \delta \dot{\varepsilon} \mathrm{Z} \dot{\eta} \nu \omega \nu$

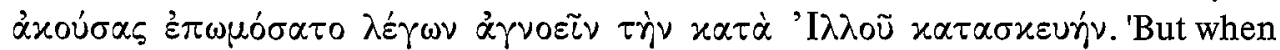
Zeno heard, he swore, saying that he knew nothing about the conspiracy against Illus.' In the first part I present the use of such pleonastic phrases in Greek with a special emphasis on their use in three Early Byzantine prose writings (in the Chronicle of John Malalas (Chr. J. Mal.), in Pratum Spirituale (Prat. Spir.), and in Vita Theodori Syceotae (Vita Th. Syc.), all belonging to the $6 \mathrm{th} / 7$ th century AD). The pleonastic phrases are studied in terms of their inner structure and in terms of their syntactic properties. In the second part of the paper an attempt is made to interpret these properties from the perspective of Naturalness Theory.

As already mentioned, the term "pleonastic phrases" subsumes cases in which a personal verbal form of a verb of speaking is accompanied by a participle of another verb of speaking. Mandilaras (1973), 364, observes the phenomenon in the Greek non-literary papyri. He states that in the papyri the pleonastic participle is regularly

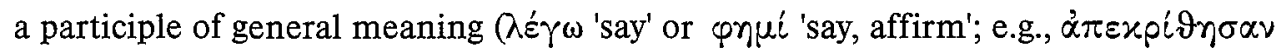
$\varphi \dot{\eta} \sigma \alpha \nu \tau \varepsilon \varsigma$ 'they answered, saying', a case cited by Mandilaras (1973), loc. cit., from the 2nd century BC), as against similar constructions in Classical Greek, in which the finite verbal form was a verb of speaking of general meaning, whereas the participle was of special (less general) meaning (the type a' $\pi$ oxp answering', example cited from Plato Prot. 314 d). ${ }^{1}$ Thus he distinguishes the "Classical" and the "Post-Classical" type.

In the papyri, the pleonastic participle is used after the verbs a'toxpivouac 'answer', $\dot{\varepsilon} \omega \omega \tau \alpha \dot{\alpha} \omega$ 'ask', and $\lambda \dot{\varepsilon} \gamma \omega$ 'say'. Such use of the participle, as Mandilaras (1973), loc. cit., states following Moulton (1911), could have risen under Semitic influence and could have been related to New Testament Greek. Semitic influence is also claimed by BDR, $\S 420$. But according to BDR, loc. cit., the same phenomena already occurred earlier in Greek, in Herodotus.

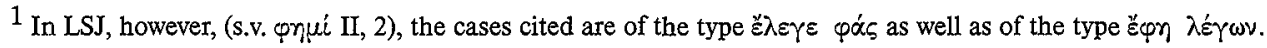


Such pleonastic phrases continued to be used in Early Byzantine Greek; cf. below, Tables I and II. In terms of their syntactic properties, in Pratum Spirituale and in Vita Theodori Syceotae all pleonastic phrases introduce direct speech, whereas in the Chronicle of John Malalas they can either introduce direct speech or govern an infinitive clause; cf. below, Table I. ${ }^{2}$ Statistically, the pleonastic phrases introducing direct speech are by far the most frequent; cf., e.g., Prat. Spir. 2932 A: $x \alpha i$ $\alpha \pi \varepsilon x p i$ in

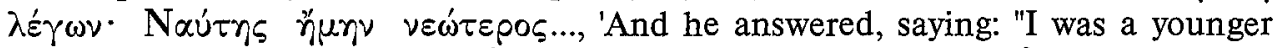

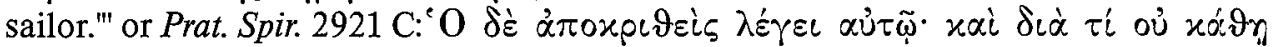

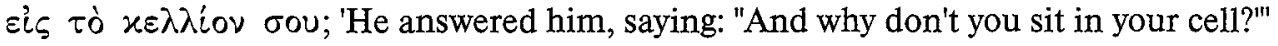
However, no finite object clauses (introduced with ö $\tau \iota)$ are attested after pleonastic phrases, although they were regularly governed by the (non-pleonastic) verbs of speaking in both Classical and Post-Classical Greek; cf., e.g., Chr. J. Mal. 2, 81, 21:

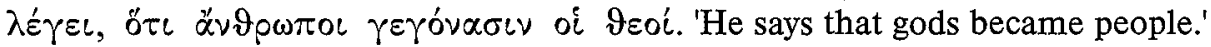

Table I- Frequency of infinitive, finite object clauses and direct speech after pleonastic phrases

\begin{tabular}{||l|l|l|l|}
\hline & INFINITIVE & FINITE OBJECT CLAUSES & DIRECT SPEECH \\
\hline Chr. J. MaL. & 3 & 0 & 13 \\
\hline Vita Th. Syc. & 0 & 0 & 24 \\
\hline Prat. Spir. & 0 & 0 & 36 \\
\hline
\end{tabular}

The following pleonastic phrases occur in the Chronicle of John Malalas, in Vita Theodori Syceotae, and in Pratum Spirituale:

Table II - Pleonastic phrases in Early Byzantine Greek

\begin{tabular}{|c|c|c|c|}
\hline & CHR. J. MAL. & VITA TH. SYC. & PRAT. SPIR. \\
\hline 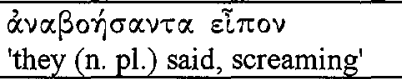 & & 1 & \\
\hline 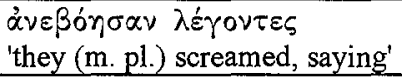 & & 2 & \\
\hline $\begin{array}{l}(\dot{\alpha} \nu \tau) \varepsilon \delta \eta^{\prime} \lambda \omega \sigma \varepsilon \nu \quad \lambda \varepsilon^{\prime} \gamma \omega \nu \\
\text { 'he revealed, saying' }\end{array}$ & & 6 & \\
\hline 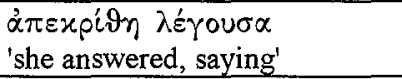 & & & 2 \\
\hline 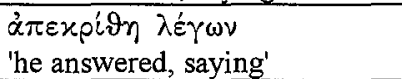 & & 1 & 7 \\
\hline 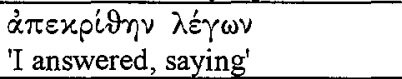 & & & 1 \\
\hline 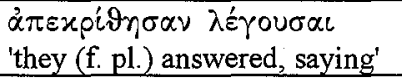 & & & 1 \\
\hline 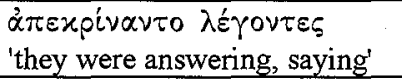 & & & 1 \\
\hline 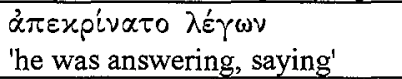 & & & 3 \\
\hline
\end{tabular}

2 In other secondary sources, I found no specific mentions of syntactic properties of pleonastic phrases. 


\begin{tabular}{|c|c|c|c|}
\hline 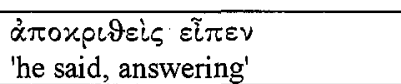 & 2 & & 4 \\
\hline 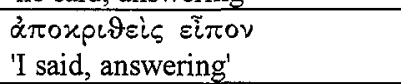 & & & 2 \\
\hline 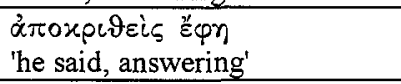 & & 1 & \\
\hline $\begin{array}{l}\dot{\alpha} \pi 0 x p c \vartheta \varepsilon i \zeta \quad \lambda \dot{\varepsilon} \gamma \varepsilon \iota \\
\text { 'he says, answering' }\end{array}$ & & & 2 \\
\hline $\begin{array}{l}\dot{\alpha} \pi 0 x p\llcorner\vartheta \varepsilon \tilde{i} \sigma \alpha \quad \varepsilon \tilde{i} \pi \varepsilon \nu \\
\text { 'she said, answering' }\end{array}$ & & & 1 \\
\hline $\begin{array}{l}\alpha \dot{\alpha} \pi 0 x \rho\left\llcorner\vartheta \varepsilon \tilde{\tau} \sigma \alpha \lambda \lambda^{\prime} \gamma \varepsilon l\right. \\
\text { 'she says, answering' }\end{array}$ & & & 2 \\
\hline 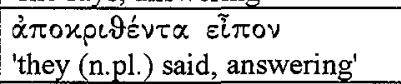 & & 1 & \\
\hline $\begin{array}{l}\delta\left(\eta \gamma \gamma \dot{\gamma} \sigma \alpha \tau 0 \lambda \hat{\varepsilon}^{\prime} \gamma \omega \nu \nu\right. \\
\text { 'he was describing [it], saying' }\end{array}$ & & 1 & 4 \\
\hline $\begin{array}{l}\dot{\varepsilon} \beta \delta^{\prime} \alpha \lambda \dot{\varepsilon} \gamma \omega \nu \\
\text { 'he was screaming, saying' }\end{array}$ & & $I$ & \\
\hline $\begin{array}{l}(\dot{\varepsilon} \nu) \hat{\varepsilon} x p \alpha \xi \varepsilon v \quad \lambda \dot{\varepsilon} \gamma \omega \nu \\
\text { 'he screamed, saying' }\end{array}$ & & 5 & \\
\hline $\begin{array}{l}\dot{\varepsilon} \pi \eta \rho \omega \tau \dot{j} \sigma \alpha \mu \varepsilon \nu \lambda^{\prime} \dot{\varepsilon} \gamma o v \tau \varepsilon \zeta \\
\text { 'we asked, saying' }\end{array}$ & & & 1 \\
\hline 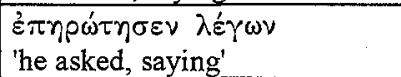 & 6 & & \\
\hline 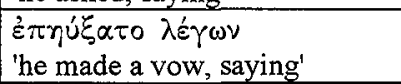 & & 1 & \\
\hline 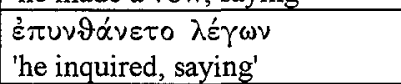 & \begin{tabular}{|l|}
1 \\
\end{tabular} & & \\
\hline $\begin{array}{l}\dot{\varepsilon} \pi \omega \mu \delta ́ \sigma \alpha \tau o ~ \lambda \hat{\varepsilon}^{\prime} \gamma \omega \nu \\
\text { 'he swore, saying' }\end{array}$ & 1 & & \\
\hline $\begin{array}{l}\varepsilon \tilde{\varepsilon} \xi \alpha \tau o \quad \lambda \dot{\varepsilon} \gamma \omega \nu \\
\text { 'he prayed, saying' }\end{array}$ & 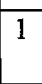 & 3 & 3 \\
\hline $\begin{array}{l}\hat{\eta} \pi \varepsilon i \lambda \varepsilon \iota \lambda \hat{\varepsilon}^{\prime} \gamma \omega \nu \\
\text { 'he was threatening, saying' }\end{array}$ & $\begin{array}{ll} \\
\end{array}$ & & \\
\hline $\begin{array}{l}\eta_{\rho} \rho \gamma \gamma^{\prime} \sigma \alpha \tau o \lambda \lambda^{\prime} \gamma \omega \nu \\
\text { 'he denied [it], saying' }\end{array}$ & \begin{tabular}{|l|}
1 \\
\end{tabular} & & \\
\hline 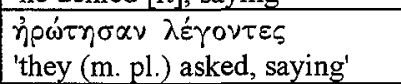 & & & 1 \\
\hline $\begin{array}{l}\pi p o \sigma \eta \dot{\xi} \xi \alpha \tau o \lambda \varepsilon^{\prime} \gamma \omega \nu \\
\text { 'he prayed, saying' }\end{array}$ & 1 & & \\
\hline 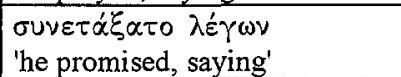 & \begin{tabular}{|l|l} 
\\
\end{tabular} & & \\
\hline 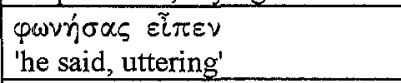 & & 1 & \\
\hline 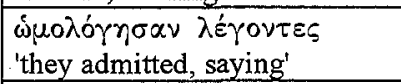 & 1 & & \\
\hline 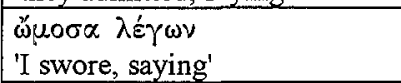 & & & 1 \\
\hline $\begin{array}{l}\lambda \dot{\varepsilon}^{\prime} \gamma \circ u \sigma \iota \\
\text { 'they say, telling myths' }\end{array}$ & 1 & & \\
\hline
\end{tabular}


As Table II shows, these pleonastic phrases are of both types, "Classical" and "PostClassical," although statistically the latter prevails (with 59 cases against 17 (reliable) cases of the Classical type). The property that applies to both types of pleonastic phrases is that the verb of general meaning (normally $\lambda \varepsilon \dot{\gamma} \gamma \omega$ 'say' and once $\varphi \eta \mu$ ' 'say, affirm') regularly follows the verb of special (less general) meaning; cf. Table II. According to BDR, the same seems to be shown by New Testament Greek: "...so

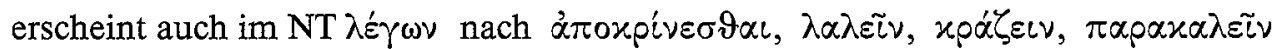
usw. in zahlreichen Beispielen." ${ }^{13}$ However, an exceptional case could be represented by

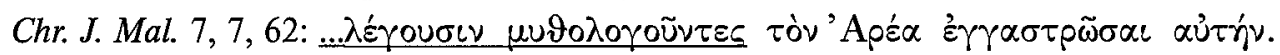
'... they say, telling myths that Ares impregnated her.' In this case, the verb of special (less general) meaning ( $\mu \cup \vartheta \vartheta^{\circ} \circ \gamma_{\tilde{\omega}}$ 'tell myths') is used in the second position. However, it is not a typical verb of speaking that would normally be used in pleonastic phrases; as the list above shows (Table II), it is not used in other cases.

\section{INTERPRETATION IN TERMS OF NATURALNESS THEORY}

This chapter attempts to interpret the use of pleonastic phrases from the perspective of Naturalness Theory, as it has developed in its most recent version at the University of Ljubljana under the guidance of Professor Janez Orešnik (the Slovenian theory). The first part briefly presents the basic principles of Naturalness Theory, whereas the second part interprets the use of pleonastic phrases in terms of Naturalness Theory.

The basic terms used in Naturalness Theory are "natural" and "naturalness". Naturalness Theory distinguishes "sem" and "sym naturalness". The term "sem natural" (abbreviated as sem) refers to naturalness from the speaker's viewpoint, and the term "sym natural" (abbreviated as sym) from the listener's viewpoint. Naturalness from the speaker's viewpoint is defined as "naturalness of an expression in terms of its semantic complexity", Orešnik (2001), 11, and naturalness from the listener's viewpoint as "naturalness of an expression in terms of its coding properties", ibid. The term "sem natural" can be replaced with the term "natural" (abbreviated as nat). Naturalness Theory sees two tendencies operating in the language, the interest of the speaker and the interest of the listener. It assumes that the two tendencies are contrary to one another.

The Slovenian theory investigates the behaviour of expressions called variants. At the earliest stages only two synonymous (syntactic) constructions could be understood as variants, e.g., a finite object clause and an infinitive clause, reported speech and direct speech. Later the term was broadened in the sense that any pair of morphological or syntactic units belonging to the same grammatical category can be taken as variants, e.g., the definite and indefinite article; cf. Orešnik (2001), 15.

When a pair of syntactic constructions are understood as variants, one of them is more sem natural and the other less sem natural. When $\mathrm{A}$ is more sem natural than $\mathrm{B}$, in the form of a naturalness scale this is expressed in the following way:

\footnotetext{
3 BDR, $\S 420,1$.
} 
$>\operatorname{sem}(\mathrm{A}, \mathrm{B})($ or $>$ nat $(\mathrm{A}, \mathrm{B}))$

Within the Slovenian theory, two additional naturalness scales are used. According to the first one, the alternative use of the less sem natural variant is more convenient for the speaker (more sem natural) than obligatory use of the less sem natural variant. The naturalness scales of this type are expressed as:

$>\operatorname{sem}(\mathrm{A}+\mathrm{B}, \mathrm{B})$

According to the other, obligatory use of the more sem natural variant is more sem natural than alternative use of the less sem natural variant:

$>\operatorname{sem}(\mathrm{A}, \mathrm{A}+\mathrm{B})$

An expanded scale $(>\operatorname{sem}(\mathrm{A}+\mathrm{B}, \mathrm{B})$ or $>\operatorname{sem}(\mathrm{A}, \mathrm{A}+\mathrm{B}))$ is true when the corresponding basic scale $(>\operatorname{sem}(A, B)$ ) is true.

Naturalness Theory assumes that the more sem natural variant tends to be used in more sem natural (less complex) circumstances than the less sem natural variant (i.e., that the more sem natural variant associates in at least one respect with a more sem natural parameter than the less sem natural variant). In the form of naturalness scales, this assumption is expressed as follows:

$>$ sem aligns with $>$ sem

$<$ sem aligns with $<$ sem

When it is taken into consideration that sem naturalness is opposed to sym naturalness, the same assumption can be expressed in other forms, e.g.:

$>$ sem aligns with < sym

or

$>$ sym aligns with $>$ sym $^{4}$

The following passage states the criteria used in the Slovenian theory in determining the naturalness value of syntactic variants; cf. Orešnik (2004), 14/5, Dobrovoljc (2005), 34. They are a fundamental contribution of the Slovenian theory to Naturalness Theory. I thank Professor Orešnik for kindly allowing me to quote the passage and adapt it to the needs of the present paper.

(A) The criterion of least effort. What conforms better to this principle is more natural. What is cognitively simple (for the speaker) is easy to produce, easy to retrieve from memory, etc.

(B) Phylogenetic age. What is older phylogenetically is more natural. What is cognitively simpler (for the speaker) is acquired earlier by the language. However, this criterion was omitted from the latest version of the theory; cf. Dobrovoljc (2005), 36.

(C) Prototypicality. What is nearer to the prototype is more natural.

(D) Degree of integration into the clause. What is better integrated into its clause is more natural. This partially exploits $(\mathrm{C})$ : the prototypical syntactic situation is for a syntactic element to be well integrated into its syntactic construction.

(E) Frequency. What is more frequent in a language tokenwise is more natural. What is cognitively simpler (for the speaker) is used more. (However, the inverse situation does not obtain: what is natural is not necessarily frequent.)

${ }^{4}$ Other forms: Orešnik (2001), 12. 
(F) Small vs. large class. The use of a unit pertaining to a small class is more natural than the use of a unit pertaining to a large class. During speech, small classes are easier for the speaker to choose from than are large classes.

(G) Specialized vs. non-specialized use. If there exists a specialized way of expressing a category, that specialized way is very natural as an expression of the category in question. If, for example, a language has reflexive personal pronouns, they are specialized to express reflexivity (whereas other personal pronouns are not specialized to express reflexivity, even if they may express it under certain circumstances), and their use to express reflexivity is very natural: > sem (+reflexive, -reflexive)/personal pronoun as expression of reflexivity.

(H) Use vs. non-use. The use of a category or process is more natural than its nonuse. This generalization is based on the following consideration. All kinds of categories occur in the most natural lexical items, paradigms, and constructions of the language, and ebb on the way out of that core. An example is a language whose noun phrases distinguish the singular, plural, and dual. Although the singular, plural, and dual are not equally natural with respect to one another, each of them is highly natural in its own field. For instance, the dual is highly natural as an expression of duality: > sem $(+,-)$ /dual in expressions of duality. This correlates with the circumstance that the dual (in fact all three numbers) is present in personal pronouns - i.e., in the most natural noun phrases - while it may be present to different degrees in the remaining noun phrases of the language.

(I) Acceptable vs. non-acceptable use. What is acceptable is more natural than what is not acceptable. The very reason for the acceptability of a syntactic unit is its greater naturalness with respect to any corresponding non-acceptable unit.

(J) What is more widespread in the languages of the world is more natural (the typological criterion). What is cognitively simpler (for the speaker) is realized in more languages.

\section{PLEONASTIC PHRASES AND NATURALNESS THEORY}

From the perspective of Naturalness Theory, the pleonastic phrases as defined above (the type é $\pi \omega \mu o ́ \sigma \alpha \tau o \lambda \varepsilon^{\prime} \gamma \omega \nu$ 'he swore, saying') are less sem natural than the non-pleonastic ones (type ह̇ $\pi \omega \mu \operatorname{có}_{\sigma} \alpha \tau$ ' 'he swore'). The latter construction is shorter and requires less effort from the speaker than the former. For this reason it is more sem natural than the former according to the criterion (A) of least effort.

It was mentioned above that a Semitic background has been suggested as a possible source of the use of pleonastic phrases in New Testament Greek. If this is so, the construction is probably not a proper case for interpretation in terms of Naturalness Theory, which interprets linguistic phenomena that develop spontaneously in a language. ${ }^{5}$ However, Semitic influence could not have been the only source because of the occurrence of pleonastic phrases in Classical Greek (cf. above).

5 Cf. Dobrovoljc (2005), 15. 
To sum up, the pleonastic phrases reveal the following properties:

- The second verb in a pleonastic phrase is of general meaning and the first one is of special (less general) meaning.

- Pleonastic phrases introduce direct speech most frequently; in several cases, a pleonastic phrase governs an infinitive clause, whereas finite object clauses are normally not dependent on pleonastic governing verbs

These properties of pleonastic phrases are explained below in Deductions I and II.

Deduction I. This deduction explains why it is expected that the second and not the first verb in any pleonastic phrase is of general meaning. Naturalness Theory claims on the basis of the criterion (A) of least effort that the second position in a pleonastic phrase is more sem natural than the first position because it is easier for the speaker to repeat a piece of information than to state it for the first time; in addition, a verb of speaking of general meaning (such as $\lambda \hat{\varepsilon} \gamma \omega$ 'say' or $\varphi \eta \mu i$ 'say, affirm' in Greek) is more sem natural than any other verb of less general meaning (such as

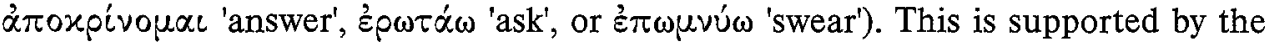
criterion (A) of least effort (a verb of general meaning is cognitively simpler for the speaker than a verb of less general meaning) and by the criterion (E) of frequency (verbs such as 'say' are more frequently used than verbs such as 'answer', 'ask', or 'swear' in any language). Consequently, the basic prediction that is used within Naturalness Theory - namely, the prediction that the more sem natural variant associates in at least one respect with a more sem natural parameter than the less sem natural variant (cf. above) - supports the prediction that within a pleonastic phrase the second verb of speaking (= the more sem natural variant) is of general meaning (= the more sem natural parameter), whereas the first verb of speaking (= the less sem natural variant) is of less general meaning (= the less sem natural parameter). This explanation is expressed in the form of a deduction as follows:

Variants: the first verb of speaking in a pleonastic phrase of the type $\dot{\pi} \pi \omega \mu$ ó $\sigma \alpha \tau o$ $\lambda \dot{\varepsilon} \gamma(\omega \nu$ 'he swore, saying', the second verb of speaking in a pleonastic phrase of the

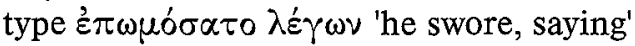

\section{Naturalness Scales:}

1.1. > sem $\left({ }^{+},-\right) /$the second verb of speaking /in a pleonastic phrase of the type

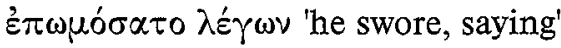

- according to the criterion (A) of least effort, $\mathrm{cf}$. above

1.2. > sem $(+,-)$ /general meaning of a verb

- according to the criterion (A) of least effort, cf. above

- according to the criterion (E) of frequency, cf. above

\section{Alignment Rules:}

2.1. $>$ sem aligns with $>$ sem

2.2. $<$ sem aligns with $<$ sem

3. Prediction: Within a pleonastic phrase of the type $\dot{\varepsilon} \pi \omega \mu o ́ \sigma \alpha \tau 0 \quad \lambda \dot{\varepsilon} \gamma \omega \nu$ 'he swore, saying', if there is any difference between the first and the second verb of speaking, in the respect that one of the two verbs of speaking is of general meaning and the other is of less general meaning, it is expected that the second verb of speaking is of general meaning and the first one is of less general meaning. 
Deduction II explains why pleonastic phrases introduce direct speech or govern an infinitive clause, although normally they do not govern finite object clauses.

Direct speech is more sem natural than indirect speech, according to the criterion (J) of typology, cf. Orešnik $(1999,32)$ : there are languages in which only direct speech is used. Infinitive clauses and finite object clauses present two types of indirect speech. In terms of Naturalness Theory, an infinitive clause is more sem natural than a finite object clause. This scale ( $>$ sem (infinitive clause, finite object clause)) is supported by the criterion (D) of integration into the clause (e.g., in Classical Greek the negative particle oúx. 'not' can be raised from an infinitive clause, a feature absent from the syntax of finite object clauses) and by the criterion (A) of least effort (one word at most is necessary to form an infinitive clause (i.e., the infinitive), whereas at most two words are necessary in the case of finite object clauses (i.e., a finite verbal form and a conjunction)). ${ }^{6}$

Consequently, the use of a finite object clause is the least sem natural of the three syntactic variants (direct speech, infinitive clause, and finite object clause), and so the following naturalness scale can be determined:

$>$ sem (direct speech/infinitive clause, finite object clause)

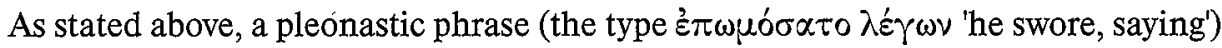
is less sem natural than a non-pleonastic one (type ह่ $\pi \omega \mu o ́ \sigma \alpha \tau 0$ 'he swore'). Consequently, if an interpretation based on the naturalness scale (> sem (-, $+)$ /pleonastic phrase) is attempted, it could not be explained why direct speech and infinitive clauses ( $=$ the more sem natural variant) associate with less sem natural parameters (i.e., with pleonastic phrases) than finite object clauses (= the less sem natural variant). As already stated, Naturalness Theory predicts that the more sem natural variant tends to associate with more sem natural parameters than the less sem natural variant.

However, it has also been observed above that, within pleonastic phrases, the second verb is of general meaning and the first one is of special (less general) meaning. In addition, a verb of general meaning is more sem natural than a verb of special (less general) meaning (cf. above). Therefore, another interpretation is possible: there is a tendency for infinitive clauses and direct speech (= the more sem natural variant) not to be dependent on verbs of speaking that are of less general meaning. For this reason, a verb of speaking of general meaning tends to be inserted between a verb of speaking of less general meaning and direct speech or the infinitive clause. This tendency (= the more sem natural parameter) is highly sem natural because a verb of general meaning is more sem natural than a verb of less general meaning. There is no such tendency in the case of finite object clauses (= the less sem natural variant). This interpretation is consonant with the assumptions of Naturalness Theory. It is expressed in the form of a deduction as follows:

Variants: finite object clauses, direct speech/infinitive clauses

${ }^{6}$ Cf. Kavčič (2004), 68, 9. 


\section{Naturalness Scales:}

1.1. > sem (direct speech/infinitive clauses, finite object clauses)

- according to the criterion (A) of least effort, cf. above

- according to the criterion (D) of integration into the clause, cf. above

- according to the criterion (J) of typology, cf. above

1.2. $>\operatorname{sem}(+,-) /$ a tendency for a governing verb to be a verb of general meaning

- according to the criterion (A) of least effort, cf. above

- according to the criterion (E) of frequency, cf. above

2. Alignment Rules:

2.1. $>$ sem aligns with $>$ sem

2.2. $<$ sem aligns with $<$ sem

3. Prediction: If there is any difference between the use of finite object clauses on the one hand and the use of infinitive clauses and direct speech on the other hand, in the respect that in one case there is a tendency for a governing verb to be a verb of general meaning and in the other case there is no such tendency, it is expected that there is no such tendency in the case of finite object clauses, whereas in the case of infinitive clauses and direct speech there is a tendency for a governing verb to be a verb of general meaning.

Remark: Another interpretation is possible: namely, that the pleonastic phrase is used particularly as an introductory phrase of direct speech (in which case the scale $>$ sem (direct speech, indirect speech) is used instead of > sem (direct speech/infinitive clauses, finite object clauses) under 1.1. in the deduction above). Judging from Table I (cf. above), the majority of pleonastic phrases introduce direct speech; the few contrasting cases all come from the Chronicle of John Malalas. However, a situation that is not predicted by Naturalness Theory would occur if the pleonastic phrases (of the structure as described above) governed only finite object clauses or if finite object clauses were more frequent after pleonastic phrases than direct speech and infinitive clauses. 
Bibliography

BDR: Blass/Debrunner/Rehkopf (1975 $\left.{ }^{14}\right)$ : Grammatik des neutestamentlichen Griechisch, Göttingen

DoBRovolJC (2005): Slovenska teorija jezikovne naravnosti, Ljubljana

KAVČIC (2004): The Greek infinitive in variable deliberative, principally dependent questions: an interpretation in terms of Naturalness Theory, in: Linguistica XLI, 59-74

LSJ: Liddell/Scott/Jones $\left(1968^{9}\right)$ : A Greek-English Lexicon, Oxford

MANDILARAS (1973): The verb in the Greek non-literary papyri, Athens

MOULTON (1911): Einleitung in die Sprache des Neuen Testaments, Heidelberg

OREŠNIK (1999): Krepke in šibke dvojnice v skladnji, Ljubljana

OREŠNIK (2001): A predictable aspect of (morpho)syntactic variants, Ljubljana

OREŠNIK (2004): Naturalness in (morpho)syntax: English examples, Ljubljana

Text editions

Chronographia Ioannis Malalae: ed. Thurn, New York and Berlin 2000

Pratum Spirituale: PG 87, 2852-3112, éd. Migne, Paris 1860

Vita Theodori Syceotae: Vie de Théodore de Sycéôn, I Texte grec, II Traduction, commentaire et appendice, éd. Festugière, Bruxelles 1970

Povzetek

\section{PLEONASTIČNA RABA GLAGOLOV GOVORJENJA V GRŠČINI: RAZLAGA S STALIŠČA TEORIJE NARAVNOSTI}

Prispevek obravnava pleonastične zveze glagolov govorjenja $v$ grščini, t.j. besedne zveze sestavljene iz po dveh glagolov govorjenja, izmed katerih je ena osebna glagolska oblika, druga pa ima obliko deležnika. Skupno takim besednim zvezam je, da se na drugem mestu praviloma uporablja glagol govorjenja bolj splošnega pomena kot je glagol govorjenja, ki je rabljen na prvem mestu. Druga skupna značilnost pleonastičnih zvez pa je ta, da (v grščini) uvajajo premi govor ali (redkeje) nedoločniški polstavek, medtem ko predmetnih odvisnikov praviloma ne uvajajo. $V$ drugem delu prispevka sta obe navedeni lastnosti pleonastičnih zvez glagolov govorjenja razloženi s stališča teorije naravnosti. 